\title{
THE DISTRIBUTION OF CATECHOLAMINES BETWEEN PLASMA AND PLATELETS IN CYCLOSPORIN A-INDUCED HYPERTENSIVE RATS
}

\author{
F. REIS, P. TAVARES and F. TEIXEIRA* \\ Institute of Pharmacology and Experimental Therapeutics, Faculty of Medicine, University of \\ Coimbra, 3004-504 Coimbra, Portugal \\ Accepted 26 June 1999
}

\begin{abstract}
One of the most serious side effects of the immunosuppressive agent, cyclosporin A (CsA), is drug-related hypertension. As it is generally accepted, the sympathetic nervous system may play an important role in the development or maintenance of this abnormal pathophysiological situation. This study is aimed at assessing plasma and platelet catecholamines, and a possible connection to cyclosporin A-induced increased arterial blood pressure. It was thus based on an investigation in which Wistar rats were divided into three groups: one taking only orange juice (control) and the other two receiving 5 and $30 \mathrm{mg} \mathrm{kg}^{-1}$ ('trough' and 'peak') of cyclosporin A (Sandimmun Neoral ${ }^{\circledR}$ ), daily, for 7 weeks. Plasma and platelet noradrenaline, adrenaline and dopamine levels and arterial blood pressures were evaluated before the start of the study (week 0) and after 2, 4 and 7 weeks. Plasma and platelet catecholamines increased drastically in the 'peak' CsA concentration-treated group, which contrasts with the slight decrease observed in the group treated with the 'trough' concentration. However, both groups revealed an increase in blood pressures, when compared with the control group. These findings suggest that at least 'peak' cyclosporin A concentration alters significantly the plasma and platelets catecholamines levels, which may contribute to the cyclosporin A-induced hypertension. Other contributions, regardless of catecholamine content disturbances, might occur, at least at 'trough' CsA concentrations.

(C) 2000 Academic Press
\end{abstract}

KEY WORDS: cyclosporin, hypertension, plasma and platelet catecholamines.

\section{INTRODUCTION}

Cyclosporin A is a potent immunosuppressive agent of significant clinical importance due to its widespread use in organ transplantation $[1,2]$ and also in the treatment of autoimmune diseases [3]. However, the therapeutic use of CsA is now seen to produce serious side effects, such as nephrotoxicity and drug-related hypertension [4-7].

The mechanism(s) involved in the CsA-induced rise in systemic arterial blood pressure remain unclear. However, several pathophysiological changes have been proposed, including: a direct CsA-induced increase in vascular smooth muscle contractility (e.g. increase in calcium influx and/or mobilization) [8-13]; a CsA-induced change in the production of vasoactive substances, such as thromboxane,

\footnotetext{
* Corresponding author. Instituto de Farmacologia e Terapêutica Experimental, Faculdade de Medicina, Universidade de Coimbra, 3004-504 Coimbra, Portugal.
}

endothelin or serotonin [14-16] or CsA-induced increase in sympathetic nerve activity. Early studies have reported increased activity of sympathetic nerves $[17,18]$ and pre-synaptic neurotransmitter release $[12,19]$ and, although the causes of the CsA-induced hypertension are undoubtedly multifactorial [see refs $[4,6,20,21]$ for review], there is evidence suggesting that sympathetic hyperactivity is involved [17-19, 22-27].

The sympathetic nervous system (SNS) can modulate cardiac output and peripheral vascular resistance, which determines arterial blood pressure. So, an abnormality in the SNS might contribute to the development or maintenance of hypertension [28, 29]. A number of studies on the connection between the SNS and hypertension have been based on measurements of plasma or tissue catecholamine (CA) concentrations. Although plasma CA physiological variability can be used to study the SNS's response to standardized stimulation, a reliable evaluation of basal SNS tone is more difficult to accomplish by 
measuring only plasma catecholamine levels. In order to overcome this problem, some authors have suggested the parallel study of platelet CA content $[30,31]$. The platelet, due to its embryogenetic, biochemical and morphofunctional features, has been proposed as a peripheral model of the monoaminergic neuron (serotonergic, in particular) [32]. However, platelets have also been shown to selectively uptake catecholamines from the plasma from many areas of the body, and to store them for relatively long periods, thus overcoming possible regional differences. Since platelets are not capable of synthesizing CA, their content derives entirely from the catecholamines released into the bloodstream by the SNS terminals and can be considered a reliable and stable long-term index of SNS activity [30, 31].

In the present study, we have evaluated both catecholamine platelet and plasma levels in rats, some of which were treated with cyclosporin A. The aim was to identify a link between possible differences between groups and changes in blood pressures, also evaluated.

\section{MATERIALS AND METHODS}

\section{Animals and diets}

Male Wistar rats (Charles River Laboratories Inc., Barcelona, Spain), $\sim 300 \mathrm{~g}$, were maintained in an air conditioned room, subjected to $12 \mathrm{~h}$ dark/light cycles, and given standard laboratory rat chow and free access to tap water. Animal experiments were carried out in agreement with the European Convention on Animal Care, and the whole research project in which these studies are included received the approval of the Portuguese National Foundation for Science and Technology. Three groups were formed: one receiving only orange juice (control) and the others receiving 5 and $30 \mathrm{mg} \mathrm{kg}^{-1}$ of CsA (Sandimmun Neoral $^{\circledR}$, Sandoz Pharma, Basel, Switzerland)-CsA (5) and CsA (30), respectively, dissolved in orange juice, daily, for 7 weeks.

Blood pressure values (systolic, diastolic and mean) were estimated using a tail-cuff sphygmomanometer. Platelet count and mean platelet volume were measured with a 'Coulter' counter.

\section{Measurements of catecholamines}

Plasma and platelet catecholamines were measured as previously described [33]. Following intraperitoneal ketamine anaesthesia, blood was withdrawn by venipuncture from the jugular vein into an anticoagulant solution $\left(0.1 \mathrm{ml} \mathrm{ml}^{-1}\right.$ blood) containing (in mM) citric acid (71), sodium citrate (85) and D-glucose (111). PRP was prepared by low-speed centrifugation (160 $\mathrm{g}$ for $10 \mathrm{~min}$, at room temperature) and then separated into platelet and plateletpoor-plasma fractions. To $2 \mathrm{ml}$ of each of these fractions, $100 \mathrm{ng} \mathrm{ml}^{-1}$ of the internal standard 3,4- dihydroxybenzylamine (DHBA), $50 \mathrm{mg}$ of alumina and $1 \mathrm{ml}$ of Tris buffer ( $1 \mathrm{M}, \mathrm{pH} 8.6)$ were added. The mixture was then shaken for $10 \mathrm{~min}$, allowed to stand for a few minutes (to sediment alumina), and the supernatant was aspirated. The alumina was then washed three times with water and transferred to an appropriate microfilter system, where adsorbed catecholamines were finally obtained by centrifugation (1000 $g$ for $1 \mathrm{~min})$ after having added perchloric acid $(100 \mathrm{~mm})$. The catecholamines were quantified by HPLC with electrochemical detection. The chromatographic system consisted of a Gilson Applied Chromatographic System with a 305 model pump and a 231 injection valve model, with a $50-\mu \mathrm{l}$ loop. A Biophase ODS RP18 analytical column (250 $\times 4.6, \varnothing=5 \mu$; Bioanalytical Systems Inc., USA) was used and separation was made possible by using an isocratic solvent system consisting of an acetate-citrate buffer (sodium acetate $0.1 \mathrm{M}$, citric acid $0.1 \mathrm{M}$ ), containing sodium octane sulphonate $(0.5 \mathrm{~mm})$, EDTA (0.15 mM), dibutylamin (1 mM) and $10 \%$ methanol. A flow rate of $1 \mathrm{ml} \mathrm{m}^{-1}$ was maintained and detection of the chromatographed catecholamines achieved by using a 141 Gilson electrochemical detector model $(650 \mathrm{mV})$.

\section{Chemicals}

Cyclosporin A (Sandimmun Neoral ${ }^{\circledR}$ ) was supplied by Novartis Farma, Portugal. All the other chemicals were of the highest analytical grade and were obtained from Sigma Chemicals, St. Louis, MO, USA.

\section{Statistical analysis}

Data are expressed as means \pm SE of the mean (SEM) of $n$ experiments. Groups were tested for differences by using the ANOVA and Fisher's test.

\section{RESULTS}

\section{Blood pressures}

Systolic (SBP), diastolic (DBP) and mean (MBP) blood pressure measurements were performed in all the rats from the control and CsA-treated groups, before starting the administrations (week 0) and after 2, 4 and 7 weeks. Significant increases in systolic, diastolic and mean blood pressures were obtained for the cyclosporin A-treated groups, after 2, 4 and 7 weeks, when compared with the control group $(P<0.05)$ (Table I).

\section{Plasma and platelet catecholamine concentra- tions}

Plasma and platelet noradrenaline (NA), adrenaline (AD) and dopamine (DA) levels were measured in the control and CsA-treated groups at week $0,2,4$ and 7 of treatment.

Plasma NA, AD and DA values for the rats of the 
Table I

The effect of cyclosporin A on blood pressures*

\begin{tabular}{lcccc}
\hline $\begin{array}{l}B P \\
(m m H g)\end{array}$ & $\begin{array}{c}\text { Treatment } \\
\text { (weeks) }\end{array}$ & $\begin{array}{c}\text { (Untreated) } \\
\text { control }\end{array}$ & $\begin{array}{c}\text { Treated } \\
\text { Cs } A(5)\end{array}$ & $\begin{array}{c}\text { Treated } \\
\text { Cs } A(30)\end{array}$ \\
\hline SBP & 0 & $165 \pm 1$ & $165 \pm 3$ & $161 \pm 1$ \\
& 2 & $163 \pm 1$ & $190 \pm 2 \dagger$ & $179 \pm 1 \dagger$ \\
& 4 & $162 \pm 2$ & $192 \pm 3 \dagger$ & $179 \pm 2 \dagger$ \\
& 7 & $164 \pm 1$ & $189 \pm 3 \dagger$ & $178 \pm 1 \dagger$ \\
DBP & 0 & $100 \pm 2$ & $89 \pm 5$ & $100 \pm 2$ \\
& 2 & $96 \pm 1$ & $119 \pm 2 \dagger$ & $114 \pm 1 \dagger$ \\
& 4 & $100 \pm 1$ & $115 \pm 1 \dagger$ & $116 \pm 1 \dagger$ \\
& 7 & $103 \pm 1$ & $114 \pm 2 \dagger$ & $112 \pm 1 \dagger$ \\
MBP & 0 & $121 \pm 2$ & $112 \pm 4$ & $120 \pm 1$ \\
& 2 & $118 \pm 1$ & $142 \pm 2 \dagger$ & $136 \pm 1 \dagger$ \\
& 4 & $121 \pm 2$ & $140 \pm 1 \dagger$ & $137 \pm 2 \dagger$ \\
& 7 & $120 \pm 3$ & $136 \pm 4 \dagger$ & $134 \pm 1 \dagger$ \\
\hline
\end{tabular}

* Data are expressed as means \pm SEM of 20 separate values.

Notes: BP, blood pressure; SBP, systolic blood pressure; DBP, diastolic blood pressure; MBP, mean blood pressure; CsA (5), Cyclosporin A (5 mg kg$\left.{ }^{-1}\right)$; and CsA (30), Cyclosporin A $\left(30 \mathrm{mg} \mathrm{kg}^{-1}\right)$.

$(\dagger)$ indicates the difference $(P<0.05)$ between the control group and each of the CsA-treated group.

control and CsA-treated groups were extremely close, before the start of administrations (week 0) (Figs 1 and 2 and Table II). After 2 weeks, there were significant increases in the NA, AD and DA plasma concentrations in the CsA (30) group $\left(\mathrm{NA}-1367 \pm 23 \mathrm{pg} \mathrm{ml}^{-1}, \mathrm{AD}-306 \pm 8 \mathrm{pg} \mathrm{ml}^{-1}\right.$ and $\mathrm{DA}-368 \pm 14 \mathrm{pg} \mathrm{ml}^{-1}$ ), when compared with the control rats $\left(\mathrm{NA}-620 \pm 24 \mathrm{pg} \mathrm{ml}^{-1}, \mathrm{AD}-256\right.$ $\pm 6 \mathrm{pg} \mathrm{ml}^{-1}$, DA- not detected and $\left.P<0.05\right)$. Inversely, plasma NA $\left(514 \pm 22 \mathrm{pg} \mathrm{m}^{-1}\right)$ and $\mathrm{AD}$ $\left(237 \pm 5 \mathrm{pg} \mathrm{ml}^{-1}\right)$ decreased in the CsA (5) group, but without statistical significance $(P<0.05)$. The same pattern of changes was noticed after 4 and 7 weeks: plasma NA and AD progressively increased in the CsA (30) group and was maintained lower, but non-significant, in the CsA (5) group, when

Table II

The effect of cyclosporin A on plasma dopamine contents*

\begin{tabular}{lllll}
\hline (pg ml & -1 \\
Group & \multicolumn{4}{c}{ Treatment period (weeks) } \\
\cline { 2 - 5 } & \multicolumn{1}{c}{2} & \multicolumn{2}{c}{4} & \multicolumn{1}{c}{7} \\
\hline Control & N.D. & N.D. & N.D. & N.D. \\
CsA (5) & N.D. & N.D. & N.D. & N.D. \\
CsA (30) & N.D. & $368 \pm 14 \dagger$ & $392 \pm 12 \dagger$ & $385 \pm 10 \dagger$ \\
\hline
\end{tabular}

\footnotetext{
*Data are expressed as means \pm SEM of ten separate values.

Notes; N.D., Not Detected; CsA (5), Cyclosporin A (5 $\left.\mathrm{mg} \mathrm{kg}{ }^{-1}\right)$; and CsA (30), Cyclosporin A (30 mg kg-1).

$\dagger$ Indicates the difference $(P<0.05)$ between the control group and each of the CsA-treated group.
}

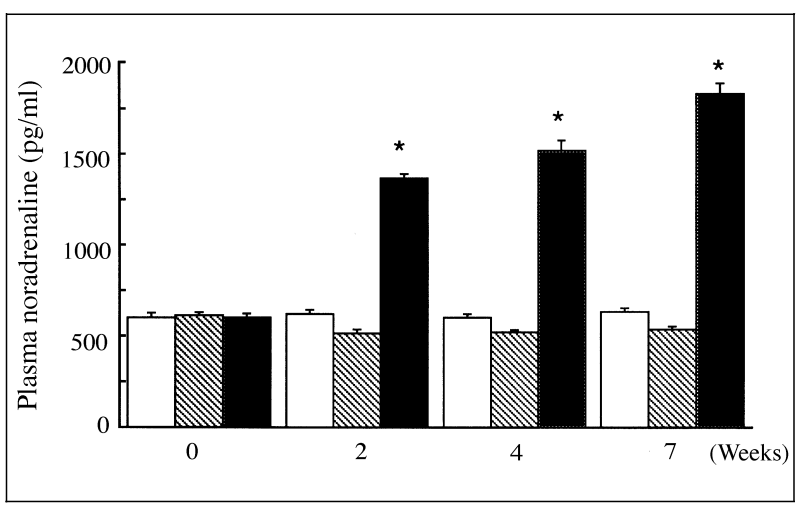

Fig. 1. Plasma noradrenaline contents in control rats and rats treated with 5 and $30 \mathrm{mg} \mathrm{kg}^{-1}$ of CsA, at weeks $0,2,4$

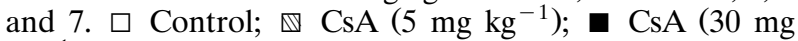
$\left.\mathrm{kg}^{-1}\right)$. Each bar represents the mean of ten different rat samples \pm SEM. $(*)$ indicates the difference $(P<0.05)$ between the control group and each of the CsA-treated group.

compared with control group (Figs 1 and 2). Plasma DA was not detected at week 0 for any group, but could be measured for the CsA (30) group, at week 2, 4 and 7 (Table II).

Before starting the treatment (week 0), similar values of platelet NA and $\mathrm{AD}$ were obtained for the control and CsA-treated groups $(P<0.05)$. Platelet DA was not detected in any group at any stage. After 2 weeks, the platelet NA rose in the CsA (30) group $\left(505 \pm 7 \mathrm{pg} \mathrm{ml}^{-1}\right)$, when compared with the control group $\left(117 \pm 3 \mathrm{pg} \mathrm{ml}^{-1}, P<0.05\right)$, contrasting with the CsA (5) group $\left(100 \pm 3 \mathrm{pg} \mathrm{ml}^{-1}\right)$ (Fig. $3)$. In the same way, the platelet $\mathrm{AD}$ increased in the CsA (30) group $\left(169 \pm 3 \mathrm{pg} \mathrm{ml}^{-1}\right)$ and decreased in the CsA (5) group $\left(100 \pm 2 \mathrm{pg} \mathrm{ml}^{-1}\right)$, when compared with the control group value $\left(134 \pm 4 \mathrm{pg} \mathrm{ml}^{-1}\right.$,

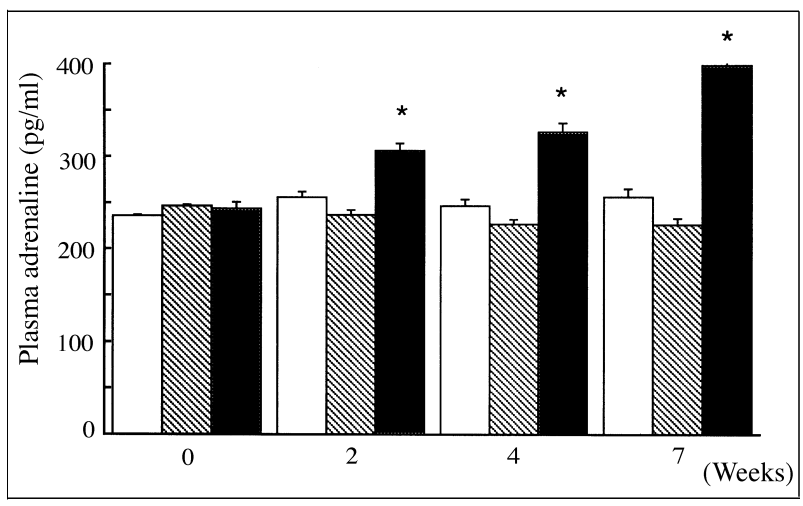

Fig. 2. Plasma adrenaline contents in control rats and rats treated with 5 and $30 \mathrm{mg} \mathrm{kg}^{-1}$ of CsA, at weeks $0,2,4$ and 7. $\square$ Control; $\mathbb{\nabla} \mathrm{CsA}\left(5 \mathrm{mg} \mathrm{kg}^{-1}\right) ; \mathbf{C s A}(30 \mathrm{mg}$ $\left.\mathrm{kg}^{-1}\right)$. Each bar represents the mean of ten different rat samples \pm SEM. $(*)$ indicates the difference $(P<0.05)$ between the control group and each of the CsA-treated group. 


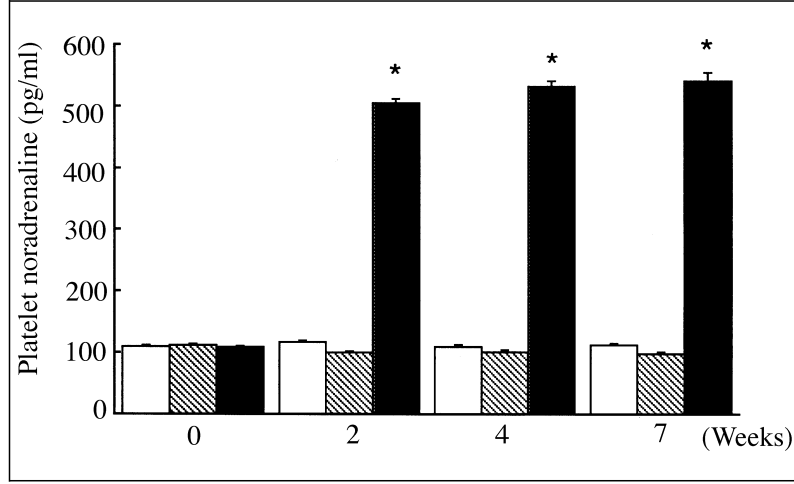

Fig. 3. Platelet noradrenaline contents in control rats and rats treated with 5 and $30 \mathrm{mg} \mathrm{kg}^{-1}$ of CsA, at weeks 0, 2, 4 and 7. $\square$ Control; $\mathbb{}$ CsA $\left(5 \mathrm{mg} \mathrm{kg}^{-1}\right)$; $\square \mathrm{CsA}(30$ $\left.\mathrm{mg} \mathrm{kg}{ }^{-1}\right)$. Each bar represents the mean of ten different rat sample \pm SEM. $(*)$ indicates the difference $(P<0.05)$ between the control group and each of the CsA-treated group.

$P<0.05$ ) (Fig. 4). The values registered after 4 and 7 weeks confirmed those obtained after 2 weeks: significant increases of NA and AD in the CsA (30)treated group and slight decreases in the CsA (5)treated group, when compared with the control group.

\section{Platelet count and mean platelet volume}

Platelet count (PLT) and volume (MPV) were also measured following 0,2 and 7 weeks of treatment. As one can see in Table III, no significant differences were obtained between the control and each of CsA-treated groups, at any stage.

\section{DISCUSSION}

In this study we have tested the effect of two

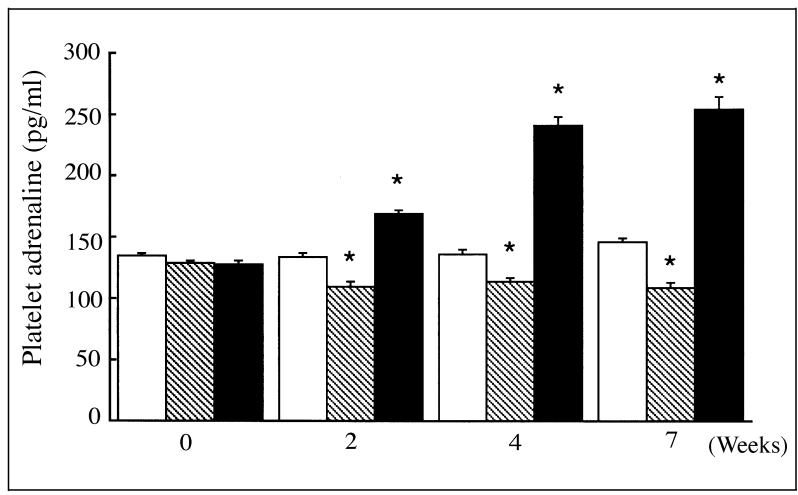

Fig. 4. Platelet adrenaline contents in control rats and rats treated with 5 and $30 \mathrm{mg} \mathrm{kg}^{-1}$ of CsA, at weeks $0,2,4$ and 7. $\square$ Control; $\mathbb{\nabla}$ CsA (5 mg kg $\left.{ }^{-1}\right)$; $\mathrm{CsA}$ (30 mg $\left.\mathrm{kg}^{-1}\right)$. Each bar represents the mean of ten different rat samples \pm SEM. $(*)$ indicates the difference $(P<0.05)$ between the control group and each of the CsA-treated group.
Table III

The effect of cyclosporin A on platelet count and volume*

\begin{tabular}{lcccc}
\hline $\begin{array}{l}\text { Group } \\
\text { parameter }\end{array}$ & $\begin{array}{c}\text { Treatment } \\
\text { (weeks) }\end{array}$ & $\begin{array}{c}\text { (Untreated }) \\
\text { control }\end{array}$ & $\begin{array}{c}\text { Treated } \\
\text { Cs } A(5)\end{array}$ & $\begin{array}{c}\text { Treated } \\
\text { Cs } A(30)\end{array}$ \\
\hline Platelet & 0 & $611 \pm 16$ & $611 \pm 16$ & $611 \pm 16$ \\
Count & 2 & $621 \pm 31$ & $611 \pm 18$ & $609 \pm 27$ \\
$\left(\times 10^{9} 1^{-1}\right)$ & 7 & $598 \pm 32$ & $573 \pm 24$ & $603 \pm 21$ \\
& 0 & $5.3 \pm 0.1$ & $5.3 \pm 0.1$ & $5.3 \pm 0.1$ \\
MPV & 2 & $5.4 \pm 0.2$ & $5.6 \pm 0.1$ & $5.6 \pm 0.2$ \\
(fl) & 7 & $5.4 \pm 0.1$ & $5.5 \pm 0.2$ & $5.6 \pm 0.1$
\end{tabular}

* Data are expressed as means \pm SEM of ten separate values. MPV, mean platelet volume; CsA(5), Cyclosporin A $\left(5 \mathrm{mg} \mathrm{kg}^{-1}\right)$; CsA(30), Cyclosporin A $\left(30 \mathrm{mg} \mathrm{kg}^{-1}\right)$. (†) indicates the difference $(P<0.05)$ between the control group and each of the CsA-treated group.

cyclosporin A doses on rat plasma and platelet catecholamines content over 7 weeks. The choice of 30 and $5 \mathrm{mg} \mathrm{kg}^{-1}$ of CsA was based on the fact that these doses corresponds to 'peak' and 'trough' CsA concentrations achieved in human blood in clinical practice, immediately after an intake of a daily dose of CsA and when the blood concentration stabilizes, respectively. As initially hypothesized, they do have different effects on catecholamines levels. So, while for the group of rats taking $30 \mathrm{mg} \mathrm{kg}^{-1}$ of CsA the plasma and platelet CA content increased significantly when compared with the control group, there was a slight decrease for the group of rats treated with $5 \mathrm{mg} \mathrm{kg}^{-1}$. The idea of test catecholamine levels between 2 and 7 weeks of treatment was based on the assumption that they reflect acute and chronic situations, respectively. In fact, 'peak' CsA concentration effects were already observed after 2 weeks and still increased until the last measurements (week 7), while the slight effects of 'trough' concentration were basically maintained after the first measurement (week 2), until the last (week 7).

Plasma and platelet catecholamines changed coherently in the two groups of CsA-treated rats. So, CsA (30) progressively increased NA, AD and DA levels in plasma as well as NA and AD in platelets, and CsA (5) slightly decreased NA and AD concentrations in the plasma and in the platelets too. As platelets lack the necessary enzymes for catecholamine synthesis, the amount of noradrenaline and adrenaline present in platelets is ultimately dependent on plasma levels. Some authors highlight this idea, suggesting that platelet CA content does not merely reflect the circulating concentrations of plasma CA, but it is rather the result of a dynamic balance between these two compartments [34]. Taking all this data into consideration, it seems that 'peak' and 'trough' CsA concentrations promoted synchronous increases and decreases, respectively, in plasma and platelet levels of catecholamines.

The role of the sympathetic nervous system in the CsA-induced increased blood pressure has already 
been studied by other investigators. Some of them emphasized the importance of sympathetic activation [17-19, 22-27], while others did not identify any significant link between the rise in blood pressure and sympathetic activation [35-37]. Even the studies on catecholamines content revealed contradictory results, reporting increases, decreases or nonsignificant changes [38-42]. Grobecker et al. [27] reported that depletion of catecholamine stores by reserpine had decreased the CsA-induced hypertension significantly. Other studies, focusing on the effects of 5, 10 and $20 \mathrm{mg} \mathrm{kg} \mathrm{g}^{-1}$ of CsA (daily administered to rats during 3 weeks) in plasma catecholamine concentration, showed interesting connections to our results. Gerkens et al. [39] obtained a decrease in the plasma NA levels for the group of rats administered with $5 \mathrm{mg} \mathrm{kg}^{-1}$ of CsA, when compared with the control group, as was also obtained by us. They did not test the effect of $30 \mathrm{mg}$ $\mathrm{kg}^{-1}$ of CsA, but found that for 10 and $20 \mathrm{mg} \mathrm{kg}^{-1}$ there were no significant differences, when compared with the control group. So, to a certain extent, our results are connected to and are an extension of those obtained by them, revealing important increases in plasma and also in platelet catecholamines (not evaluated in their study) for a higher CsA concentration than those tested by them.

In our study blood pressures rose significantly in both CsA-treated groups, despite a decrease in plasma and platelet catecholamine levels in the group treated with the 'trough' CsA concentration (5 $\left.\mathrm{mg} \mathrm{kg}{ }^{-1}\right)$. These data suggest that, despite altered CA distribution in the plasma and platelets could represent an important factor for the CsA-induced hypertension at high doses, other different contributions should be expected, at least when CsA is administered in low doses. CsA-induced increased catecholamine metabolization, namely by increased monoamineoxidase (MAO) activity, could explain normal and even lower plasma and platelet catecholamines levels than those of the control, despite of greater blood pressure increases, when compared with the high CsA concentration. However, this effect was not tested and, it remains as a speculation. On the other hand, as already demonstrated in other studies carried out in our laboratory, the 'trough' CsA dose $\left(5 \mathrm{mg} \mathrm{kg}^{-1}\right)$ is able to promote important changes in the platelet 5-HT and TXA $_{2}$ content and aggregation [43], factors that may be also involved in the development of hypertension. However, we can say that, at least 'peak' CsA (30 $\left.\mathrm{mg} \mathrm{kg}^{-1}\right)$ dose promotes important changes in the sympathetic nervous system, which results in increased plasma and platelet catecholamines content that may certainly affect platelet function and vascular smooth muscle cell response. Both adrenaline and noradrenaline, to less extent, induce platelet aggregation in vitro, but the concentrations required to promote in vivo responses are far lower than circulating plasma levels.
However, catecholamines amplify the effects of other agonists and, at higher concentrations, induce platelet response, including aggregation, secretion and arachidonate pathway activation [44]. On the other hand, increased circulating catecholamines content could represent increased stimulation of vascular smooth muscle $\alpha$-adrenergic receptors. As $\alpha_{1}$ and $\alpha_{2}$ adrenergic receptors can mediate vasoconstriction in most vascular beds, hyperresponsiveness of vascular smooth muscle to $\alpha$ adrenergic receptor-mediated vasoconstriction is probably a key factor involved in the development and/or maintenance of high vascular resistance, which determines hypertension.

The mechanisms by which the high dose of cyclosporin A increased plasma and platelet catecholamines level cannot be addressed considering only the data presented in this paper. Anyway, increased NA, AD and DA concentrations suggest, at least, that CsA may affect their synthesis, namely by the adrenals, or their release from sympathetic nerve endings. Previous studies realized in our laboratory [45] demonstrated that the catecholamines level in the rat adrenals did not change significantly when submitted to the same cyclosporin A dose $(30 \mathrm{mg}$ $\mathrm{kg}^{-1}$ ), suggesting that increased circulating catecholamines may result from increased release from the nerve endings. Therefore, this hypothesis was already formulated by Xue et al. [12] but still remains without an undoubtedly confirmation. However, our previous data seems to be in agreement with that since, in aorta segments obtained from rats treated with the same dose of CsA, the endogeneous catecholamines content decreased significantly when compared with the control ones [45, 46]. On the other hand, increased ${ }^{3} \mathrm{H}-\mathrm{NA}$ release in the presence of CsA was also observed, which reinforce these supposition [45, 46]. Anyway, further studies are needed in order to clarify the origin and confirm the relevance of circulating catecholamines to the CsA-induced hypertension.

\section{ACKNOWLEDGEMENTS}

This work has the kind collaboration of Novartis Farma, Portugal, which supplied the cyclosporin A (Sandimmun Neoral ${ }^{\circledR}$ ). Also, our special thanks to the Fundação para a Ciência e Tecnologia, for supporting this project financially (PRAXIS/ $\mathrm{PSAU} / \mathrm{C} / \mathrm{SAU} / 57 / 96)$.

\section{REFERENCES}

1. Borel JF, Di Padova F, Mason J, Quesniaux V, Ryffel B, Wenger R. Pharmacology of cyclosporine (Sandimmune). I. Introduction. Pharmacol Rev 1989; 41: $239-42$. 
2. Kahan BD. Cyclosporine. N Engl J Med 1989; 321: 1725-38.

3. Langford CA, Klippel JH, Balow JE, James SP, Sneller MC. Use of cytotoxic agents and cyclosporine in the treatment of autoimmune diseases. Ann Intern Med 1998; 129: 49-58.

4. Schachter M. Cyclosporine A and hypertension. $J$ Hypertens 1988; 6: 511-16.

5. Mimran A, Mourad G, Ribstein J, Halimi J-H. Cyclosporin-associated hypertension. In: Hypertension: pathophysiology, diagnosis and management. 2nd ed. Laragh JH, Brenner BM, eds. New York: Raven Press, 1995: 2459-69.

6. Sander M, Victor RG. Hypertension after cardiac transplantation: pathophysiology and management. Curr Opin Nephrol Hypertens 1995; 4: 443-51.

7. Ventura HO, Malik FS, Mehra MR, Stapleton DD, Smart FW. Mechanisms of hypertension in cardiac transplantation and the role of cyclosporine. Curr Opin Cardiol 1997; 4: 375-81.

8. Haller H, Spies K, Lindschau C, Quass P, Distler A. The effects of cyclosporine on calcium, protein kinase $\mathrm{C}$ and sodium proton exchange in platelets. Transplantation 1994; 57: 1516-20.

9. Bokemeyer D, Kramer HJ, Meyer-Lehnert H. Cyclosporine A enhances total cell calcium independent of Na-K-ATPase in vascular smooth muscle cells. Clin Invest 1994; 72: 992-5.

10. Bokemeyer D, Kramer HJ, Meyer-Lehnert H. Atrial natriuretic peptide blunts the cellular effects of cyclosporine in smooth muscle. Hypertension 1993; 21: 166-72.

11. Lamb FS, Webb RC. Cyclosporine augments reactivity of isolated blood vessels. Life Sci 1987; 40: 2571-8.

12. Xue H, Buroski RD, McCarron DA, Bennett WM. Induction of contraction in isolated rat aorta by cyclosporine. Transplantation 1987; 43: 715-18.

13. Rego A, Vargas R, Suarez KR, Foegh ML, Ramwell PW. Mechanism of cyclosporine potentiation of vasoconstriction of the isolated rat mesenteric arterial bed: role of extracellular calcium. J Pharmacol Exp Ther 1990; 254: 799-808.

14. Jorkasky DK, Fisher CA, Stahl RF, Addonizio VP, Glickman JD. The effects of cyclosporine on human platelet aggregation and thromboxane release. Transplant Proc 1989; 21: 948-9.

15. Haug C, Duell T, Voisard R, Lenich A, Kolb HJ, Mickley V, Homback V, Grunert A. Cyclosporine A stimulates endothelin release. J Cardiovasc Pharmacol 1995; 26: S239-S241.

16. Malyszko J, Pawlak D, Pawlak K, Malyszko JS, Buczko W, Azzadin A, Mysliwiec M. Platelet aggregation and peripheral serotonergic system in kidney transplant recipients treated with cyclosporine. Transplant Proc 1996; 28: 1954-7.

17. Moss NG, Powell SL, Falk RJ. Intravenous cyclosporine activates afferent and efferent renal nerves and causes sodium retention in innervated kidneys in rats. Proc Natl Acad Sci USA 1985; 82: 8222-6.

18. Murray BM, Paller MS, Ferris TF. Effects of cyclosporine administration on renal hemodynamics in conscious rats. Kidney Int 1985; 28: 767-74.

19. Golub MS, Berger ME. Direct augmentation by cyclosporin A of the vascular contractil response to nerve stimulation. Hypertension 1987; 9: 96-100.

20. Oskarsson HJ, Hofmeyer TG, Olivari MT. Cyclosporine impairs the ability of human platelets to mediate vasodilation. Hypertension 1997; 29: 1314-21.

21. Tavares P, Martínez-Salgado C, Eleno N, Teixeira F, López Novoa JM. Effects of cyclosporin A on rat smooth-muscle cell proliferation. J Cardiovasc Pharmacol 1998; 31: 46-9.

22. Scherrer U, Vissing SF, Morgan BJ, Rollins JÁ, Tindall RSA, Ring S, Hanson P, Mohanty PK, Victor RG. Cyclosporine-induced sympathetic activation and hypertension after heart transplantation. $N$ Engl $J$ Med 1990; 323: 693-9.

23. Morgan BJ, Lyson T, Scherrer U, Victor RG. Cyclosporine causes sympathetically mediated elevations in arterial pressure in rats. Hypertension 1991; 18: 458-66.

24. Lyson T, McMullan DM, Ermel LD, Morgan BJ, Victor RG. Mechanisms of cyclosporine-induced sympathetic activation and acute hypertension in rats. Hypertension 1994; 23: 667-75.

25. Chiu PJ, Vemulapalli S, Sabin C, Rivelli M, Bernardino V, Sybertz EJ. Sympathoadrenal stimulation, not endothelin, plays a role in acute pressor response to cyclosporine in anesthetized rats. J Pharmacol Exp Ther 1992; 261: 994-9.

26. Sander M. Sympathetic neural mechanisms of cyclosporine-induced hypertension. Am J Hypertens 1996; 9: $121 \mathrm{~S}-138 \mathrm{~S}$

27. Grobecker HF, Riebel K, Wellenhofer T. Cyclosporine A-induced hypertension in SHR and WKY: role of the sympatho-adrenal system. Clin Exp Pharmacol Physiol 1995; 1: S94-S95.

28. Mancia G, Di Rienzo M, Giannattasio C, Parati G, Grassi G. Early and late sympathetic activation in hypertension. Scand Cardiovasc J Suppl 1998; 49: 9-14.

29. Prados P, Santa T, Homma H, Doi H, Narita H, Del Castillo B, Martin MA, IMAI K. Comparison of the sympathetic nervous system activity between spontaneously hypertensive and Wistar-Kyoto rats to respond to blood pressure reduction. Biol Pharma Bull 1997; 20: 341-4.

30. Chanberlain KG, Pestell RG, Best JD. Platelet catecholamine contents are cumulative indexes of sympathoadrenal activity. Am J Physiol 1990; 259: 141-7.

31. Ueda E, Kuchii M, Hano T, Ueno Y, Jo Y, Shima H, Nishio I, Masuyama Y. Platelet noradrenaline content as an integrated measure of variations in plasma noradrenaline. Jpn Circ J 1990; 54: 383-90.

32. Stahl SM. Platelets as pharmacologic models for the receptors and biochemistry of monoaminergic neurons. In: The platelets: physiology and pharmacology. Longenecker GL, eds. London: Academic Press, 1985: 307-40.

33. Smith CCT, Curtis LD, Delamonthe AP, Prichard BNC, Betteridge DJ. The distribution of catecholamines between platelets and plasma in normal human subjects. Clin Sci 1985; 69: 1-6.

34. Blandini F, Martignoni E, Sances E, Bono G, Nappi G. Combined response of plasma and platelet catecholamines to different short-term stress. Life Sci 1995; 56: 1113-20.

35. Kaye D, Thompson J, Jennings G, Esler M. Cyclosporine therapy after cardiac transplantation causes hypertension and renal vasoconstriction without sympathetic activation. Circulation 1993; 88: 1101-9.

36. Elam M, Casale R, La Rovere M-T, Mortara A, Tavazzi L. Is sympathetic neural hyperactivity in chronic heart failure affected by heart transplantation? Eur Heart J 1993; 14: 521-5.

37. Stein CM, He H, Pincus T, Wood AJ. Cyclosporine impairs vasodilation without increased sympathetic activity in humans. Hypertension 1995; 26: 705-10.

38. Duruibe VA, Okonmah A, Panton L, Blyden GT. 
Effect of cyclosporin A on rat kidney catecholamines. Life Sci 1990; 47: 255-61.

39. Gerkens JF. Cyclosporine treatment of normal rats produces a rise in blood pressure and decreased renal vascular responses to nerve stimulation, vasoconstrictors and endothelin-dependent dilators. $J$ Pharmacol Exp Ther 1989; 250: 1105-12.

40. Thompson ME, Shapiro AP, Johnsen AM, Itzkoff JM, Hardesty RL, Griffith BP, Bahnson HT, McDonald RH, Hastillo A, Hess M. The contrasting effects of cyclosporin-A and azathioprine on arterial blood pressure and renal function following cardiac transplantation. Int J Cardiol 1986; 11: 219-29.

41. Bellett M, Cabrol C, Sassano P, Léger P, Corvol P, Ménard J. Systemic hypertension after cardiac transplantation: Effects of cyclosporine on the reninangiotensin-ald-osterone systems. Am J Cardiol 1985; 56: $927-31$.

42. Steigerwalt SP, McCurdy R, Smith S, Lockette W.
Role of the sympathetic nervous system in cyclosporine hypertension following orthotopic cardiac transplantation in man. Kidney Int 1987; 31: 309.

43. Reis F, Tavares P, Fontes Ribeiro CA, Ferrer Antunes $C$, Teixeira $F$. The peripheral serotonergic system and platelet aggregation in cyclosporin Ainduced hypertensive rats. Thromb Res 1999: in press.

44. Anfossi G, Trovati M. Role of catecholamines in platelet function: pathophysiology and clinical significance. Eur J Clin Invest 1996; 26: 353-70.

45. Teixeira F, Tavares P, Reis F, Fontes Ribeiro CA. The effect of cyclosporin on catecholamine levels in plasma, platelets, aorta and adrenals. Pharmacol Toxicol 1998; 83(Suppl 1): 107.

46. Tavares P, Fontes Ribeiro CA, Teixeira F. Cyclosporin-induced hypertension is probably due to alterations in catecholamine storage and release. Naunyn-Schmiedeberg's Arch Pharmacol 1998; 358 (Suppl 1): R249. 